\title{
Economic thought in the capitalist system as a determinant of social, economic and technological development
}

\begin{abstract}
Capitalist society in its progression stage has created a pronounced contradiction. On the one side, productive forces and technology have been developed towards a more humane social stage while, on the other, surplus value has come to belong exclusively to the private owners of capital. This has led to class stratification and moral dilemmas. The consequences of these contradictions lie in various forms of alienation, as well as in the positions and outcomes of labour and labour struggle. The materialisation of this process is verified in the form of giant corporations and is conditioned by social development (industrial revolution and internationalisation processes). The effects of such social, economic and technological development have led to a deepening of the global class structure and to social reification, expressed in three classes: workers; managers; and capital owners. Constellations of divisions are based on the role that individuals actually adopt in certain economic relationships and social life, and their position in the realm of productive forces.
\end{abstract}

Keywords: economic development, economic globalisation, capitalism, alienation, capital, class, labour, human development, social stratification, income distribution, technology, collectivism, surplus value

\section{Introduction}

Modern society has accelerated the progress of all elements of human society and that which humans have created. In that direction, much of society occupies an exalted status, emphasising the contradictions. Class distinctions are the primary effect as well as the direct result of our model of economic and technological development. Technology contributes to a better maximisation of human society, but the complexity of development implies the production of surplus value which will itself facilitate, at the same time, further technological progress. However, on the other hand, it will also create greater social stratification. The consequences of such development will be the creation of economic classes as a replacement for social classes.

In such a social constellation, collectivism increasingly dominates individualism and economic, social and technological determinism; while class order signifies growing levels of social alienation and reification, expressed as a three-class group of collectives: employees; managers; and owners of capital. The interests of individuals are individual, related to their particular economic class, while decisions are a collective responsibility. 


\section{Development of economic thought conditioned by technological development}

The capitalist system began to develop a strand of economic thought, separating economics as a science from a range of philosophical inputs. The importance of economic growth in the development of society and social thought can be found in the thinking of Plato and Xenophanes (Jakšić and Pejić, 2001: 11), despite their negative views on trade as a form of monetary exchange, but, at the same time, not neglecting the importance of the natural economy. Aristotle, in his philosophical considerations, does not ignore the issue of trade and the value of money, and is thus considered to have contributed to the development of economic thought.

Significant discoveries have contributed to the expansion of trade in emerging markets. However, in terms of young nation-states, government assistance has been required to develop new manufactures. This stage was characterised by a certain forerunner of today's monopoly organisation because, with the help of the state, some companies received a kind of imperial power. This form of trade was renamed 'merchant capitalism' and was characteristic of the period from the fifteenth to the seventeenth centuries.

However, we must emphasise the dawn of alienation and social stratification at the very beginning of the development of capitalism. Society needs a labour class; formerly slaves, or serfs, but in capitalism known as workers. The worker gains freedom, but also the freedom of his or her results, i.e. of their surplus value. This class Engels referred to as the middle class (Engels, 1881).

There then followed a new phase of economic development, in which capitalist society experienced strong growth. Economy and society prospered, thanks to technological developments and discoveries. The industrial revolution brought technological progress, which directly implied economic prosperity via the additional increase in surplus value, as well as a new market liberalisation in terms of the function of the valorisation of the surplus value.

Economists have argued on the topics of free market, competition and monopoly production, but there is an even greater stratification in society. Engels's middle class, as a creator of modern manufactures in terms of the function of the creation of benefits to society as a whole, takes on a new role - that of paid managers; on the other side, the owner of capital finds a role as a passive controller.

With the development of industry and the invention of the steam engine, society entered a phase of industrial capitalism in the nineteenth and twentieth centuries. With its several instruments, the state sought to accelerate technological progress, shape the workforce through the education system, invest in infrastructure and the environment and, taking risk in this context, to subsidise unprofitable industries, etc. (Horvat, 1982: 30). Here, we may recognise the stage of development that economists call 'state monopoly capitalism'. Previous determinants led to a strengthening of the relationship between states and also created a worldwide international economy materialised in the international market but which, at the same time, has changed the civilisation heritage of nation-states in global social norms.

The rapid development of capitalism, with the help of the state, opened up the field of the internationalisation of the economy, which indicates planning on an international 
basis and going beyond national borders. The consequence can be found right in the multinational and transnational companies that crossed state borders, referring to the stage of 'corporate capitalism', commencing in the twenty-first century (DragičevićRadičević, 2010: 159). This phase of capitalism is bringing great changes in social organisation and our system of values.

Additionally, we may identify that alienation is extending even to the owners of capital. Engels argued:

The social function of the capitalist here has been transferred to servants paid by wages; but he continues to pocket, in his dividends, the pay for those functions though he has ceased to perform them. (Engels, 1881)

Also, the second argument of Engels is interesting:

Thus we see that by the very development of the system of capitalists' production the capitalist is superseded quite as much as the handloom-weaver. With this difference, though, that the handloom-weaver is doomed to slow starvation, and the superseded capitalist to slow death from overfeeding. In this they generally are both alike, that neither knows what to do with himself. (Engels, 1881)

Imposing new challenges on current economic trends opens a new chapter in economic theory. On the one hand, we have the opening of markets, the establishment of global values in relation to their local setting, the overcoming of time and space limitations, the dissemination of knowledge, the migration of capital and labour, and the linking of people, cultures and economics; while, on the other hand, we have the polarising power and the specific division of labour which have introduced the concept of class stratification in society. This is a consequence of the differentiation of opposites and the contradictions in the system of social production, originally resulting in the alienation of work and its results after the industrial revolution. After that, the internationalisation of production relations has been materialised within giant corporations. All this has created a new form of alienation between the owners of capital and capital managers. This has led to a system of social reification, as well as complete alienation and objectification of people.

The biggest critic of this arrangement, Karl Marx, emphasises the contradiction. On the one hand, there is the development of productive forces and technology towards the assumption of a more humane social stage. At the same time, there is also this appropriation of surplus value solely by the private owners of capital and the consequent experience of class stratification (even though capitalism seeks to be perceived as a society without classes) and moral dilemmas. This creates unsustainable notions as regards the further development of capitalism (Dragičević-Radičević and Gavrilović, 2013: 86).

Based on the above considerations, it is clear that, in a society based on capitalism, two assumptions are dominant: the first is irrational and ideological, stemming from an analysis of individuals and their positions in society; while the other is rational materialised within the contribution of the technology industry and the rapid development of society. One might observe the irrational side of society, and on the other its 
rational side, but capitalist society receives both sides. Both are in a process of acceleration. First is the acceleration of technological progress; and the second, brought by the first, is the acceleration of the alienation of human beings from themselves.

If we start from Engels's interesting assumption and interpretation of Marx's Das Kapital, labour is the source of wealth and a measure of value. But there are also socalled accumulated works in the form of capital which, with extra resources, can multiply the productivity of human labour. Hence, what is being developed here is the right of compensation in the form of profits, but also an inconsistency which, with the development of capitalist society, is received in a materialised form. However, there is also a new social form, due to issues that remain with no answer, and that is how we must seek to resolve the contradiction between:

The capital of capitalists constantly growing bigger, while rents from pure labour are becoming less, and the masses of workers living solely from rents becoming more numerous and poorer. (Marx, Engels, 1949: 26)

The process of shaping the new order has led to the emergence of large corporations that have sought vertical and horizontal mergers in terms of controlling the market and their competitors, and shaping the new consumer culture. With the coming of the large corporations, there has been a major change in the status of the labour force. The contribution of capitalism has been such that the workforce has become the subject of trade on the labour market, on which workers sell their labour for certain levels of compensation and, through various forms of trade unions, engage in negotiations with the owners of capital to price the terms and cost of labour.

Working as an engine of productive relations, this may be seen not only in terms of productivity, but also in terms of the ethical and moral principles that apply. Moral values remain constant, but certain systems of social order, such as the capitalist mode of production, through a process of alienation from the creators of work, open a new chapter in the overall system of social relations (Dragičević-Radičević and Gavrilović, 2013: 86). This indicates a direct relationship between class stratification, the attributes of capitalism and established social norms and principles.

\section{Social stratification - attributes of capitalist development}

The industrial revolution led as a result to the alienation of labour and thus contributed to the contradictions and discrepancies in the system of social production. The internationalisation of economic activity has led to the materialisation of the new relations of production in the form of multinational and transnational corporations. Social relations have taken on a new form of reification and alienation between the owner and manager of capital. At the same time, the synergistic effects of new social relationships, miraculously resulting in technological development, starting with the industrial revolution, have led to new social forms and the creation of new forms of social classes, which are based on economic class. There is a new system of social reification, materialised in the objectives of certain social classes. On this basis, a new global order is being built which represents the unity of the economic, technological and social orders. 


\section{Economic thought in the capitalist system as a determinant of social, economic and techno- logical development}

The basic features of the new system are an economic collectivism in capital management, in opposition to the rising individualism of giant corporations and their alienation from the environment in which they operate. Furthermore, technology, innovation and knowledge are increasingly taking on the dimensions of globalism, inducing a determinant of collectivism and the technological order.

By this analogy, the social order ought to be based on collectivism, but is it? Considering the previous statements, we may note that society is only in one sense based on collectivism, in the form of the three class groups, but the goals are individual, representing the interests of each one. In these processes of collectivism, three classbased collectivist groups may clearly be noted: worker; manager; and capital owner.

Classes differentiate according to their roles in the system of social production, according to their relation with the means of production, according to the manner of keeping their existence, according to their role in distribution and the possession of surplus value and according to their role in the cultural and political life of the country, as well as according to specific class psychology. (Vranicki, 1962: 70-71)

Modern society is a very classed society, based on individuals and their economic position in society, and in connection with the creation and distribution of surplus value, which is directly correlated with technological advance.

Therefore, the development of technology implies the efficiency of the workforce and the amount of the creation of surplus value. According to the teachings of Marx, the worker produces surplus value, and receives only a portion thereof, while the manager has both paid and unpaid surplus value; meanwhile, the capitalist appropriates all the unpaid surplus value. Surplus value is the collective factor of the individual subjects of the economy in a capitalist society, but is also a driver of technological development.

In class societies (all societies based on goods-monetary exchange are class ones), an individual obeys the class norms of the economic class to which he/she belongs. Those norms represent a symbiosis of all social, ethical and moral rules and tendencies, materialised in their economic position. In such a way, one may speak of the reification of morality within classes, which leads to ever more expressed class stratification and alienation, due to the different availability and possibility of managing the labour surplus. In other words, morality is not the same for a worker, a manager and a capital owner. Each of them individually satisfies their own needs implementing, at the same time, their reification. The reification of the class struggle is a serious development in the case of workers in their eternal existential struggles to dispose of their own labour. The dominant stage of the moral struggle here becomes the trade union struggle. Managers realise the reification of morality through compensation and bonuses, and through status which assumes their managerial position, while capital owners have become alienated from their own capital and the possibilities of its management, realising moral reification through profit. (Dragičević-Radičević and Gavrilović, 2013: 90)

\section{Conclusion}

Surplus value, as a standard of the capitalist system, has led to the creation of new forms of economic, social and technological development. Social classes have been replaced by economic classes, while technological development has become conditioned by individual goals for individual classes, but primarily for the industrialised 
class in maintaining their position. There are defining forms of social, moral, ethical and other standards. In this way, the assumption has been confirmed that technological development is reaching a more humane social stage and that the complexity of this development implies the creation of surplus value. Ultimately, this also allows for conditional technological development and economic prosperity, but it adds at the same time to social stratification.

\section{References}

Dragičević-Radičević, T and M. Gavrilović (2013) 'Corporate economy - agnosticism materialized in the class distinctions' Fifth International Scientific Conference Moral effect of economy and Economic effect of morality Higher Educational Institution for Applied Studies of Entrepreneurship, Centre for Industrial Relations and Institute for Economical Agriculture, Belgrade, p. 83-91.

Dragičević-Radičević, T (2010) 'Korporativni kapitalizam, kraj jedne doktrine-apstrakcionizam ili kreativna destrukcija’ Politička revija IX Vol. 25 br. 03/2010, Institut za političke studije: Beograd.

Engels, F (1881) Društvene klase - neophodne i suvišne izvor: Marksistička internet arhiva, www.marxists.org [last accessed: 30 August 2013).

Horvat, B (1982) The Political Economy of Socialism M. E. Sharpe, Armonk: New York (translation: Globus Zagreb).

Jakšić, M and L. Pejić (2001) Razvoj ekonomske misli Ekonomski fakultet: Beograd.

Marx, K and F. Engels (1949) Izabrana dela u dva toma Tom 1, Kultura.

Vranicki, P (1962) Dijalektički i historijski materijalizam Matica hrvatska: Zagreb. 